\title{
STUDY ON THE EFFECT OF POLYETHYLENE TEREPHTALATE COMPRESSIVE STRENGTH OF CONCRETE
}

\author{
UMI LATIFAH \\ Faculty of Engineering \\ University of Mercu Buana Jakarta, Indonesia \\ Miellha10@gmail.com \\ SYAFWANDI \\ Faculty of Engineering \\ University of Mercu Buana Jakarta, Indonesia \\ syafwandi@menarasiswa.co.id
}

\begin{abstract}
Plastic waste is the largest contributor in the world and belongs to the class of materials that can not be broken down by organisms (non bio-degradable) and durable (persistent) which does not rot. It can be seen directly from this waste is its light weight and not easily deformed. Terephtalate polyethylen plastic types are widely used as mineral water bottles can be recycled as coarse aggregate for lightweight concrete manufacture. In this study, carried out the loading test compressive strength. To determine the properties of lightweight concrete, tested the modulus of elasticity, compressive strength, and strong Pull. The physical and mechanical nature of light concrete in the use of waste plastics PET instead of coarse aggregate must be in accordance with existing regulations. The compressive strength of concrete with the highest in the age of 28 day care that is equal to $23.973 \mathrm{MPa}$. The highest tensile strength value contained in the concrete to the age of 28 day care that is equal 2,782Mpa.
\end{abstract}

Keywords: Polyethlen Terephtalate (PET), compressive strength, artificial aggregate.,

\section{INTRODUCTION}

Plastic waste is a very common problem in urban areas and rural areas. The use of plastics in each year will continue to increase for food products, beverages all using materials made of plastic. However, plastic is plastic which is hard to get contaminated with dirt or commonly called inorganic waste, which is difficult to self-destruct. This is what causes the amount of plastic waste involved increases. Therefore, to reduce plastic waste in addition be used as a craft of this increased plastic waste was diverted utilization in development. In this study the use of waste plastic bottles to do further research their use as raw material for coarse aggregate.

The results of the processing of coarse aggregate light obtained from the burning plastic bottle beverage packaging is recycled or Polyethylene terepthalate (PET) were used in the concrete mix that has the objective to find out how big the contribution or influence of coarse aggregate, lightweight on the characteristics of lightweight concrete, especially the structural properties of lightweight concrete resulting from.

In the present study, the authors will try to do research using PET waste with a mixture presentation $0 \%, 5 \%, 10 \%, 15 \%, 20 \%$ of coarse aggregate is used. 


\section{Review of Literature}

Concrete is a mixture of Portland cement or other hydraulic cement, fine aggregate, coarse aggregate, and water, with or without additional (admixture). Along with the addition of age, the concrete has hardened and will reach kekutan plan (fc ') at the age of 28 days.[1]

Lightweight aggregate is an aggregate that has a crumbly oven dry weight of a maximum of $1100 \mathrm{~kg} / \mathrm{m}^{3}$. Lightweight aggregate also has a density (specific gravity) is low, about 1/3-2 / 3 of normal weight aggregate types. Bulk density and density of these aggregates is strongly influenced by the gradation and the size of the aggregate itself.

The essence of lightweight aggregate is an aggregate that has a lighter specific gravity, high porosity and low thermal conductivity, which can be produced from natural aggregates as well as the results of fabricating the so-called artificial aggregate (artificial aggregate). However there are some problems that arise when using the lightweight aggregate is the ease of workmanship (workability) and completion (finishability) concrete is low, increasing the tendency toward segregation, it is difficult to determine the value of an effective water-cement factor and the strength of the resulting concrete will likely decrease.

\subsection{Aggregate characteristics of light}

\section{a. Particle Shape and Surface Aggregate}

The shape and texture of the surface will affect the proportion of concrete mix, as workabilitas, the ratio of sand to aggregate, cement content and water requirements.

\section{b. Specific gravity}

Lightweight fine aggregate having a specific gravity greater than mild coarse aggregate. Coarse aggregate lighter specific gravity ranging from 1/3-2 / 3 of normal weight aggregate types.

\section{c. The content of Water and Power Absorption of Aggregate}

Lightweight aggregate absorption power is much higher than normal aggregate because it is porous. Based on absorption test for 24 hours, lightweight aggregate can absorb $5 \%-20 \%$ by weight of the dry lightweight aggregate, whereas normal aggregate only absorb $2 \%$ by weight.

\section{d. aggregate size}

The maximum size of lightweight aggregate generally used is $3 / 4$ inch (19 mm), or $1 / 2$ inch (13 $\mathrm{mm}$ ) or $3 / 8$ inch $(10 \mathrm{~mm})$. The maximum size of this lightweight aggregate effect on the workability, the ratio of sand to aggregate, cement content, air content optimum, level of strength and shrinkage.

\section{e. The strength of aggregate}

Lightweight aggregate is generally weaker than normal aggregate. Although there is no definite link between the strength of aggregate and concrete strength will be generated, but the concrete strength is often not qualified to wear lightweight aggregate concrete.

\section{2. lightweight concrete}

Lightweight concrete lightweight concrete aggregate is made using lightweight aggregates which are porous and have a low specific weight (less than 2.6). Bulk density of concrete produced is $300-1850 \mathrm{~kg} / \mathrm{m}^{3}$ dan between 0.3-0.4 MPa compressive strength.

The purpose of this normal use of fine aggregate to increase the strength of lightweight concrete, tractable level (workability) and the elastic modulus of the lightweight concrete.

The modulus of elasticity of concrete depends on the number of mortar of cement and aggregates as well as the modulus of each of its constituent materials. Normal concrete modulus 
of elasticity has a value greater because the value of the sand and gravel modulus greater than the modulus of structural lightweight aggregate.

Polyethylene terephthalate (PET) is a thermoplastic polyester commercially produced through the condensation products are characterized by a number of ester bond that is distributed along the polymer main chain. Poyethylene terephthalate (PET) is the basic material of plastic water bottles, with its IUPAC name polioksi neooksitereftaoil ethylene.

PET and other polyesters generally free darihasil hazardous combustion $\mathrm{CO} 2$. The melting point of pure PET Aast $280^{\circ} \mathrm{C}$ for sample "annealing" is complete. Whereas commercial products melt at a temperature of $255^{\circ} \mathrm{C}-265^{\circ} \mathrm{C}$, because the results kristalisaai reduced by the noise in the main chain. Impurities present in the PET mengekibatkan kekuatn products will be reduced, either as a film or fiber product. The glass transition point vary within wide intervals depend on the purity of the polymer.

Polyethylene terephthalate (PET) can be dissolved in m-cresol hot, trifluoro acetic acid, oklorofenol, has a crystalline melting point that is high enough around $270{ }^{\circ} \mathrm{C}$ and excellent mechanical properties, resistance to chemical treatments, hydrolytic and solvent. PET is used in the technique pemlastik as a replacement for steel, aluminum in the manufacture of electronic materials.

Lightweight coarse aggregate from waste plastic bottles (PET) can be as an alternative to lightweight coarse aggregate is generally used in structural lightweight concrete mix, both in terms of power and economy. [2].

Based on quality standards and testing requirements of ASTM C300-00, "Standard Specification for Lightweight for Structural Concrete", and SNI 03- 2461-1991, "Lightweight Aggregate Specifications for Concrete Structures", performed on artificial coarse lightweight aggregate from waste plastic bottles PET that rugged lightweight artificial aggregate of plastic waste can be used as a lightweight aggregate in lightweight concrete mixture. [3].

\section{RESEARCH METHODOLOGY}

In the utilization of PET plastic waste into a mixture of coarse aggregate concrete production, the method used is the experimental method. Tests performed include materials testing, compressive strength and tensile strength. Stages of research conducted, among others:

a. Stages of preparation and testing of the test specimen:

At this preparatory stage to prepare the equipment and materials to be used in testing. The main materials used are coarse aggregate, fine aggregate, cement and water. On testing materials testing for fine aggregate and coarse aggregate.

b. Preparation of Test Objects

Preparation of test objects determine the variation of PET waste mixture that will be used. In this research PET waste to be used as a mixture of coarse aggregate is $0 \%$, $5 \%, 10 \%, 15 \%$ and $20 \%$. Tests conducted on samples at the age of 7 days, 14 days and 28 days.

c. Maintenance and Testing Test Objects

After the manufacture of the test object and then perform maintenance on a sample which aims to avoid cracks in the concrete surface and the desired quality in testing can be achieved. 
In the testing phase of the test specimen that has been made to test the compressive strength and tensile strength test and then recorded the results.

d. The discussion and analysis of the test data.

The discussion and analysis carried out after the test specimen obtained data collection that is determining the mechanical properties of concrete with a mixture of PET, comparing the compressive strength of normal concrete and concrete that has been mixed with PET waste. In addition to compressive strength in tensile testing was also performed.

\section{RESULT AND DISCUSSION}

In the present study the manufacture of cylindrical samples to test compressive strength. PET waste mixture with a percentage of $0 \%, 5 \%, 10 \%, 15 \%$ and $20 \%$.

The proportion of concrete materials used are as follows:

Table 4.1 Proportion of Mixed Concrete

\begin{tabular}{|c|c|c|c|c|c|c|}
\hline \multirow[b]{2}{*}{ No } & & \multicolumn{5}{|c|}{ Komposisi Material (Kg) } \\
\hline & Sample & Air & Semen & $\begin{array}{c}\text { Agregat } \\
\text { Halus }\end{array}$ & $\begin{array}{c}\text { Agregat } \\
\text { Kasar }\end{array}$ & $\begin{array}{c}\text { Limbah } \\
\text { PET }\end{array}$ \\
\hline & 0\% Limbah & & & & & \\
\hline \multirow[t]{2}{*}{1} & PET & 9,7 & 27,5 & 63,5 & 57,5 & - \\
\hline & $5 \% \quad$ Limbah & & & & & \\
\hline \multirow[t]{2}{*}{2} & PET & 9,7 & 27,5 & 63,5 & 54,625 & 2,875 \\
\hline & $10 \%$ & & & & & \\
\hline \multirow[t]{2}{*}{3} & Limbah PET & 9,7 & 27,5 & 63,5 & 51,75 & 5,75 \\
\hline & $15 \%$ & & & & & \\
\hline \multirow[t]{2}{*}{4} & Limbah PET & 9,7 & 27,5 & 63,5 & 48,875 & 8,625 \\
\hline & $20 \%$ & & & & & \\
\hline 5 & Limbah PET & 9,7 & 27,5 & 63,5 & 37,375 & 11,5 \\
\hline
\end{tabular}

Source: Data Processing 
In a mortar / concrete mix, water content is of considerable concern because it determines the level of workability. Liquid concrete mix that is too low will lead to concrete quality, and long drying. While the concrete mix is too dry causes the mortar is uneven and difficult to print.

Table 4.2 Test Slump Test Results

\begin{tabular}{|c|c|c|}
\hline No & Sample & $\begin{array}{c}\text { Nilai Slump } \\
\text { Test Beton } \\
(\mathrm{cm})\end{array}$ \\
\hline 1 & Beton Variasi PET 0\% & 10 \\
2 & Beton Variasi PET 5\% & 10,4 \\
3 & Beton Variasi PET 10\% & 11,3 \\
4 & Beton Variasi PET 15\% & 12,1 \\
5 & Beton Variasi PET 20\% & 12,6 \\
\hline
\end{tabular}

Source: Data Processing

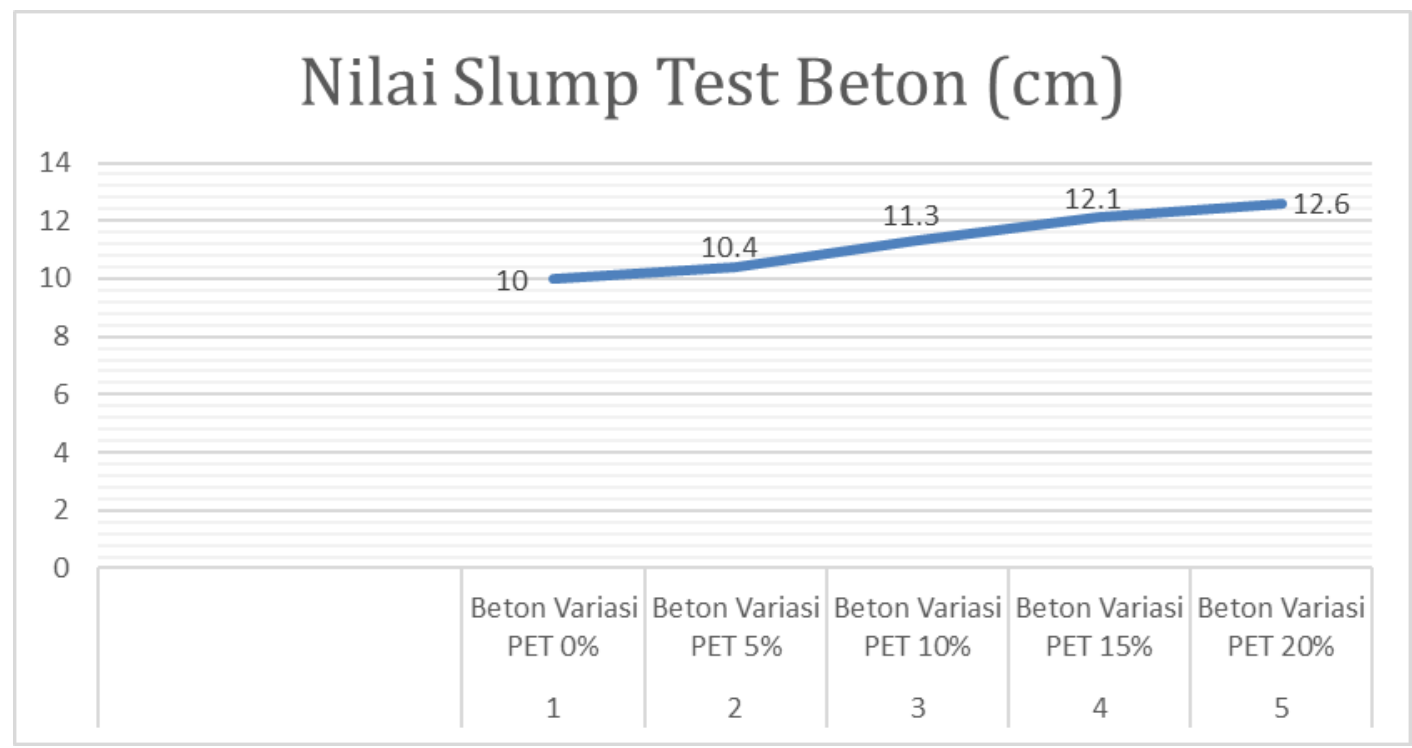

Figure 4.1 Graph Slump Test Results

Source: Data Processing

Based on the results of research and reading charts stated that the slump test value ranges between $80 \mathrm{~mm}-130 \mathrm{~mm}$, which is categorized as plastic slump. Thus the data obtained above for testing slump test value can be concluded more and more levels of PET plastic waste mixture added to the value of the additional concrete slump will decrease. This will result in concrete with the addition of a mixture of PET waste levels in large numbers it will be difficult to do in the field.

Table 4.4 Results of Tests on Lightweight Aggregate Plastic PET 


\begin{tabular}{|l|c|c|c|}
\hline \multicolumn{1}{|c|}{ Pengujian } & Hasil Latifah & Hasil Dwisetyowati & Hasil Wiryawan \\
\hline Apperent Specific Gravity & 2,030 & 1,346 & 1,322 \\
\hline Bulk Specific Gravity & 1,336 & 1,321 & 1.316 \\
\hline Absorpsi (\%) & 0,113 & 1,42 & 1,14 \\
\hline Kadar Air (\%) & 0 & 0 & 0 \\
\hline
\end{tabular}

Source: Data Processing

In Table 4.4 shows considerable differences in the levels of absorption in plastic lightweight aggregate between research results are now done with the studies conducted earlier. This difference can be seen that the aggregate ability to absorb water Umi lower than the aggregate ability Shinta and Sony in absorbing water. This is not surprising where at the time of casting, a lot of water that needs to be added to get the value of the slump to be achieved.

Results of testing the strength of concrete to form a cylinder here, is the result of testing the strength of concrete that has aged for 7 days, 14 days and 28 days. The purpose of the concrete compressive strength test here is to determine the effect of a mixture of PET waste. The results of the testing for compressive strength cylinders made in the present study are:

Table 4.6 Data Lightweight Concrete Compressive Strength

KUAT TEKAN BETON

\begin{tabular}{|c|r|r|r|r|c|}
\hline Hari & $\begin{array}{c}\text { Beton } \\
\text { Variasi 0\% } \\
\text { PET (MPa) }\end{array}$ & $\begin{array}{c}\text { Beton } \\
\text { Variasi 5\% } \\
\text { PET (MPa) }\end{array}$ & $\begin{array}{c}\text { Beton } \\
\text { Variasi } \\
10 \% \text { PET } \\
\text { (MPa) }\end{array}$ & $\begin{array}{c}\text { Beton } \\
\text { Variasi } \\
15 \% \text { PET } \\
\text { (MPa) }\end{array}$ & $\begin{array}{c}\text { Beton } \\
\text { Variasi } \\
20 \% \text { PET } \\
\text { (MPa) }\end{array}$ \\
\hline 7 & 15,14 & 13,742 & 13,357 & 13,187 & 12,915 \\
\hline 14 & 17,785 & 15,816 & 14,388 & 14,226 & 13,067 \\
\hline 28 & 23,364 & 23,973 & 21,447 & 17,643 & 15,437 \\
\hline
\end{tabular}

Source: Data Processing 


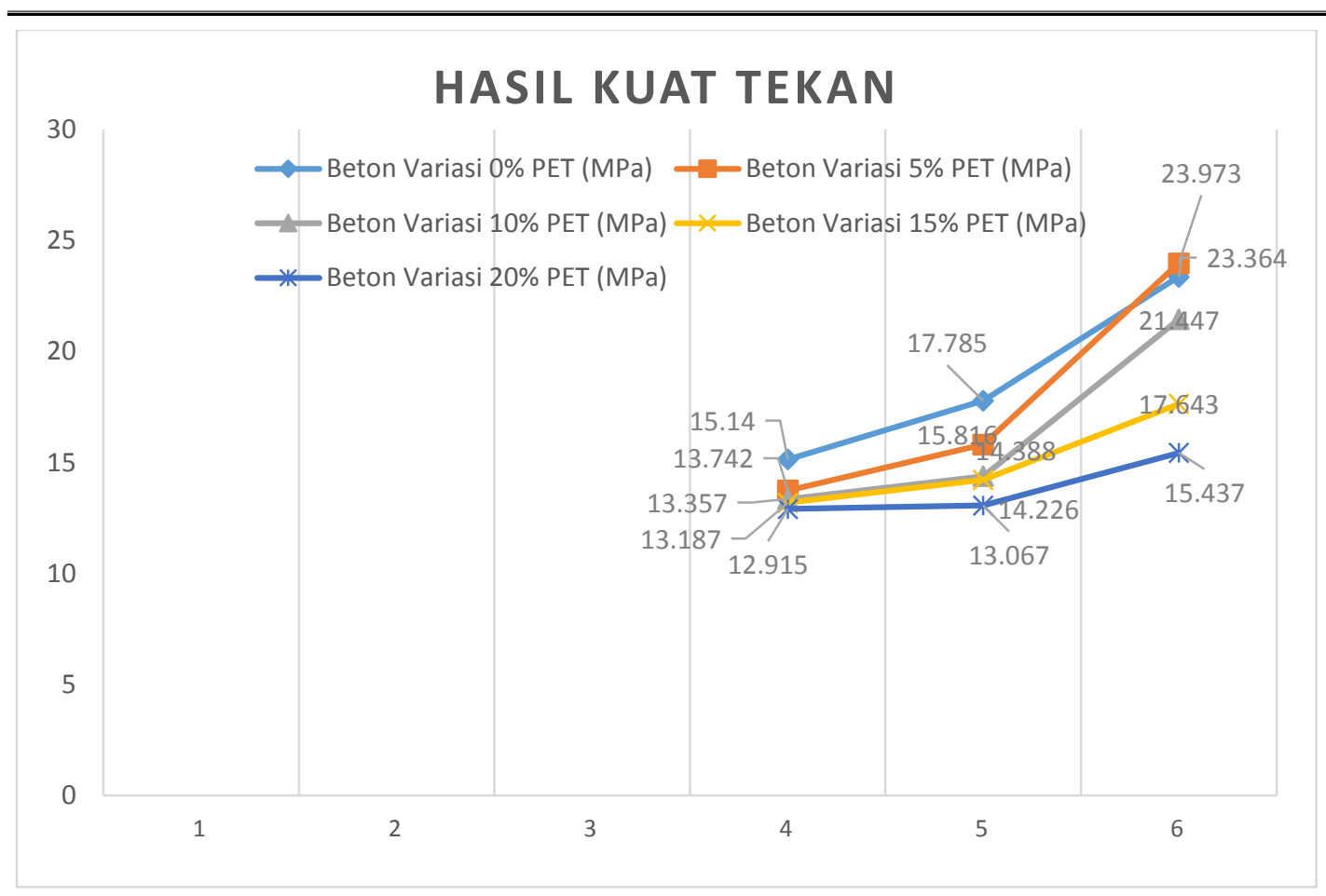

Figure 4.4 Graph results for Concrete Compressive Strength

Source: Data Processing

The results of compressive strength obtained is presented in Table 4.6 has undergone various experiments to obtain the expected compressive strength or compressive strength approaching the minimum expected. Before finally getting the compressive strength is expected, this study did mix trial conducted to obtain the compressive strength of the expected plan. The compressive strength of the plan is expected in the form of a cylinder the size $(15 \times 30) \mathrm{cm}$ during the 28 days that is expected is approximately $25 \mathrm{MPa}$.

Poisson's ratio is the ratio between the strain laterally to stretch the horizontal direction.

Table 4.7 Testing Results Modulus of Elasticity and poison Ratio

\begin{tabular}{|l|l|l|}
\hline $\begin{array}{l}\text { type } \\
\text { Concrete }\end{array}$ & $\begin{array}{l}\text { Modulus of } \\
\text { Elasticity (Mpa) }\end{array}$ & $\begin{array}{l}\text { Poisson's } \\
\text { Ratio }\end{array}$ \\
\hline Cylinder & 6784 & $0: 25$ \\
\hline
\end{tabular}

Source: Data Processing

4.7 In the table above, we can see the results of testing the elastic modulus and Poisson ratio. Values obtained poisson ratio remains beyond the normal limits where the value of the Poisson ratio for normal concrete is about 0.15 to 0.20 . 
Tests conducted in the present study is to obtain the value of the tensile strength of concrete by dividing the maximum load that causes specimen fracture with a field of breakage. The data on the tensile strength of concrete is as follows:

Table 4.8 Strong Pull Concrete Testing Results

KUAT TARIK BETON

\begin{tabular}{|c|r|r|r|r|r|}
\hline Hari & $\begin{array}{c}\text { Beton } \\
\text { Variasi 0\% } \\
\text { PET (MPa) }\end{array}$ & $\begin{array}{c}\text { Beton } \\
\text { Variasi 5\% } \\
\text { PET (MPa) }\end{array}$ & $\begin{array}{c}\text { Beton } \\
\text { Variasi } \\
10 \% \text { PET } \\
(\mathrm{MPa})\end{array}$ & $\begin{array}{c}\text { Beton } \\
\text { Variasi } \\
15 \% \text { PET } \\
(\mathrm{MPa})\end{array}$ & $\begin{array}{c}\text { Beton } \\
\text { Variasi } \\
20 \% \text { PET } \\
(\mathrm{MPa})\end{array}$ \\
\hline 7 & 2,547 & 2,659 & 2,265 & 1,885 & 1,854 \\
\hline 14 & 2,663 & 2,375 & 2,354 & 2,107 & 1,977 \\
\hline 28 & 2,682 & 2,782 & 2,411 & 2,183 & 1,996 \\
\hline
\end{tabular}

Source: Data Processing

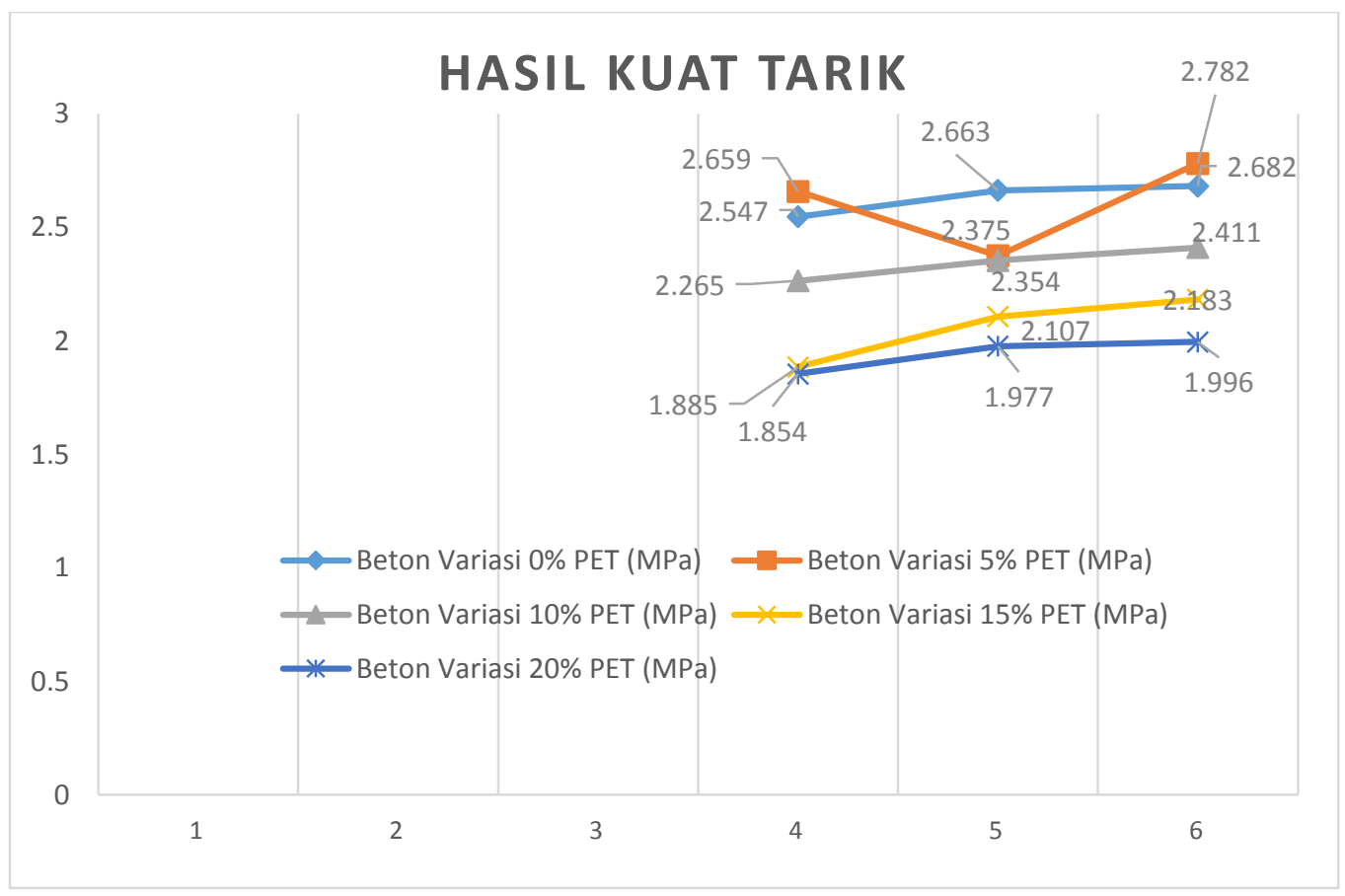

Figure 4.8 Graph Strong Pull

Source: Data Processing

From the reading of the data of Tables and Figures it can be seen that the value of flexural strength / tensile highest is concrete with a variation of shredded plastic waste by $5 \%$ at the age of 28 day care that is $2.782 \mathrm{MPa}$. Based on testing both compressive strength and flexural strength / tensile shows that variation of $5 \%$ shredded waste plastics packaging of mineral water as a partial replacement of fine aggregate in the concrete mix can deliver better results as compared to conventional concrete. 


\section{CONCLUSION}

Based on research and analysis of the results process that I do and refers to previous studies it can be concluded that:

1. Based on the calculation results showed that the compressive strength of concrete is highest at the age of 28 day care that is equal to $23.973 \mathrm{MPa}$ for concrete mixes with $5 \%$ shredded waste plastics packaging of mineral water. The compressive strength with a variation of $5 \%$ mixture of shredded waste plastics packaging of mineral water is included in the provision of quality concrete $\mathrm{K} 300$, which required concrete compressive strength (fc ') at 28 days is $25 \mathrm{MPa}$.

2. The magnitude of the modulus of elasticity obtained through this experiment was for 6784 .

3. Values obtained poisson ratio remains beyond the normal limits where the value of the Poisson ratio for normal concrete is about 0.15 to 0.20 .

4. Based on the test results the value of flexural strength / tensile conducted showed that the highest value is concrete with a variety of chopped mineral water packaging plastic waste by $5 \%$ at the age of 28 day care that is equal to $2.782 \mathrm{MPa}$.

Based on both testing both compressive strength test and the test of flexural strength / tensile shows that variation of $5 \%$ shredded waste plastics packaging of mineral water as a partial replacement of fine aggregate in the concrete mix can deliver better results as compared to conventional concrete.

\section{REFERENCES}

[1] SNI 2847-2013. Requirements Structural Concrete for Buildings Building. (2013). Jakarta: BadanNational Standardization.

[2] Dwisetyowati, Shinta. (2008). "Study of Mechanical Properties Properties of Concrete Using Coarse Aggregates of Plastic Type polyethylen Terephtalate (PET), Thesis, Depok

[3] Wiryawan, Sony Aria., (2007) "Study of Artificial Lightweight Coarse Aggregate Characteristics of Waste Plastic Bottles Terephtalate polyethylene (PET) and Coarse Aggregate Effects of Artificial Light on Mechanical Properties of Concrete Properties of Light." Thesis, Jakarta.

[4] Alfiandi, DG (2016). Influence of PET Plastic Waste As Lightweight Aggregate Concrete Structural Coarse On. USU Civil Engineering Journal, 5 (1).

[5] ASTM C 39. (2002) .test Method for Compressive Strength of Cylindrical Concrete Spesimens, Annual Book of ASTM Standards. United States of America.

[6] ASTM C-348-97. (2005) Standardized Tests Method for Flexural Strength of Hydraulic Cement Mortar, Annual Book of ASTM Standards. USA.

[7] Derucher, KN, Heins, CP (1981). "Materials for Civil and Highways Engineers", New Jersey: Prentice Hall, Inc., Englewood Cliffs.

[8] Ehrig, RJ (eds) (1993). "Plastic Recycling", Oxford University Press, New York.

[9] Ramadhani, MF, Basuki, A., \& Supriyadi, A. (2015). Strong Bending Test In Concrete Panel Beragregat Rugged Plastic Waste PET and Wiremesh Reinforcement. Matrix of Civil Engineering, 3 (4).

[10] Suwarno, A. (2016). Study of Plastic Waste Usage For Mixed Concrete Aggregates. Forum for the Civil Engineering: Civil Engineering Development Journal, 20 (1).

[11] Wibowo, Budi Agung. S., (2002). "Capacity Bending and Slide Beams Reinforced with Fiber Addition Exploiting Plastic Plastic Bottle Material Used / polyethylen Terephtalate (PET)." Research Report, Surakarta. 